\title{
Effect of salt stress on antioxidant enzymes and lipid peroxidation in leaves in two contrasting corn, 'Lluteño' and 'Jubilee'
}

\author{
Libertad Carrasco-Ríos ${ }^{1}$, and Manuel Pinto ${ }^{2}$
}

\begin{abstract}
Salinity is an important problem to crop production; affecting photosynthesis process which favors the production of reactive oxygen species. Plants have generated adaptation strategies to prevent oxidative damage caused by salinity. In this study we evaluated the effect of salinity on lipid peroxidation and antioxidant enzymes in leaves of corn (Zea mays L.) plants 'Lluteño' (adapted to salinity) and 'Jubilee' (improved variety). 'Lluteño' is the only one corn capable to prosper in the Valley of Lluta under saline conditions $\left(\mathrm{EC}=9.1 \mathrm{dS} \mathrm{m}^{-1}\right)$ and the most widely cultivated crop in terms of area in the desert of northern Chile. Plants of $21 \mathrm{~d}$ old were subjected for $15 \mathrm{~d}$ to two saline treatments: 50 and $100 \mathrm{mM} \mathrm{NaCl}$. Salinity caused a significant reduction in plant biomass, ca. $65 \%$ in 'Jubilee' and $20 \%$ in 'Lluteño' $(\mathrm{P} \leq 0.05)$. The biomass reduction and oxidative damage to cell membranes caused by the generation of peroxides was significantly less in 'Lluteño'. The activity of superoxide dismutase (SOD), catalase (CAT), guaiacol peroxidase (GPX), and ascorbate peroxidase (APX) in 'Lluteño' was significantly greater than in 'Jubilee' in all treatments, while glutathione reductase (GR) had greater activity in 'Jubilee'. However, most enzymes studied were adversely affected by salinity compared to the control. These results indicate that tolerance to salinity exhibited by 'Lluteño' should in part due to the high activity that exhibit antioxidant enzymes compared to 'Jubilee'.
\end{abstract}

Key words: Antioxidant enzymes, lipid peroxidation, salt stress, Zea mays.

\section{INTRODUCTION}

Salinity causes a decrease in the growth of cultivated plants, since salts affect a number of physiological processes such as photosynthesis, stomatal conductance, osmotic adjustment, ion absorption, protein and nucleic acid synthesis, enzymatic activity, and hormone balance (Hernandez et al., 2000). It also affects transport of ions and water, which promotes ionic toxicity and nutritional imbalance (Munns and Tester, 2008).

The effects of salinity also have an oxidative component derived from the limitation of the photosynthetic rate which occurs in conditions of drought and salinity (Lawlor, 1995; Filella et al., 1995; Munns, 2002). If under saline stress plants are not capable of photosynthetic transformation of all the solar energy they receive, the energy excess may produce an increase in singlet and triplet forms of chlorophyll and singlet oxygen. The decrease of $\mathrm{NADP}^{+}$pool with excess excitation energy causes an increase in the flow of electrons from the donor

${ }^{1}$ Universidad de Tarapacá, Facultad de Ciencias, Velásquez 1775, Arica, Chile. "Corresponding author (lcarrasc@uta.cl).

${ }^{2}$ Instituto de Investigaciones Agropecuarias INIA, Santa Rosa 11610, La Pintana, Santiago, Chile.

Received: 12 July 2013.

Accepted: 16 January 2014.

doi:10.4067/S0718-58392014000100014 part of photosystem I (PSI) to oxygen, generating reactive oxygen species (ROS) (Johnson et al., 2003), produced principally in chloroplasts, which provoke metabolic disorders such as oxidation of membrane lipids, proteins and nucleic acids (Imlay, 2003).

Plants have enzymatic and non-enzymatic antioxidation mechanisms which may counteract adverse effects of salinity. The former include enzymes superoxide dismutase (SOD), catalase (CAT), guaiacol peroxidase (GPX), ascorbate peroxidase (APX), and glutathione reductase (GR); while the latter include compounds such as ascorbate, glutathione, flavonoids, and vitamins $\mathrm{C}$ and E (Noctor and Foyer, 1998). Therefore, an imbalance between production of free radical species and systems of cellular antioxidant defense would produce the appearance of oxidative stress. The cell damage which results from an excess of free oxygen radicals has been explained as a consequence of an alteration of cell membrane produced by oxidation of acids of the lipid bilayer, a process known as lipid peroxidation. This generates changes in chemical composition and deterioration in ultrastructure of cell membranes, decreasing their fluidity, altering their permeability, and inactivating enzymes and membranelinked receptors (Mansour and Salama, 2004).

Since salinity is an important cause of oxidative stress, in this study we evaluated the activity of antioxidant enzymes expressed in two corn (Zea mays L.) cultivars: 'Lluteño' (the only one corn capable to prosper in the 
valley of Lluta under saline conditions $-\mathrm{EC}=9.1 \mathrm{dS} \mathrm{m}^{-1}$ and the most widely cultivated crop in terms of area in the desert of northern Chile) and 'Jubilee' (improved variety, normally cultivated in the North of Chile in non-saline soils), which have different levels of tolerance to salt stress (Carrasco-Ríos et al., 2013). The specific objectives of the study were: i) to evaluate the oxidative damaged caused by salinity, and ii) evaluate the relative importance of the enzymatic antioxidant mechanisms in salt tolerance.

\section{MATERIAL AND METHODS}

\section{Plant material and experimental conditions}

The study was performed at the Experimental Station of the Tarapacá University (18 31'2" S, 70¹0'34" W) using young plants of 'Lluteño' and 'Jubilee' corn, this last is a corn variety bred (Syngenta, Wilmington, Delaware, USA) commercialized in Chile by Bioamerica S.A. Seeds were sown in plastic pots containing perlitevermiculite $1: 1(\mathrm{v} / \mathrm{v})$ as substrate. To keep humidity, pots were covered with a plastic wrap until epicotyls appeared 4 to $5 \mathrm{~d}$ after sowing. Then plants were cultivated for 2 wk under greenhouse conditions where mean maximum temperature was $35{ }^{\circ} \mathrm{C}$ and mean relative humidity was $34 \%$. Along this time, plants were cultivated in hydroponic conditions using a non-saline Hoagland solution (Arnon and Hoagland, 1940). Twenty one days after sowing, plants were randomly placed outdoors and subjected to the treatments for $15 \mathrm{~d}$ (Table 1). During the experiment, midday photosynthetically active radiation (PAR) intensity was $2200 \mu \mathrm{mol} \mathrm{m} \mathrm{m}^{-2} \mathrm{~s}^{-1}$, mean maximum temperature $27.6{ }^{\circ} \mathrm{C}$ and mean minimum $16.9{ }^{\circ} \mathrm{C}$. The relative humidity averaged $50 \%$ in the day and $80 \%$ in the night.

\section{Dry matter accumulation and $\mathrm{Na}$ content measurements}

After $15 \mathrm{~d}$ of saline treatments, five plants per treatment were harvested and divided into leaves, stems, and roots, for their respective fresh (FW) and dry weight (DW) determination. Dry weight was obtained after drying each part of the plant in an oven at $80^{\circ} \mathrm{C}$ for $48 \mathrm{~h}$. Accumulation of DM was expressed as the plant weight at the end of treatments minus the weight of plants recorded at the beginning of treatments. For $\mathrm{Na}^{+}$analysis, samples of dried leaves and roots were ashed in a furnace at $500{ }^{\circ} \mathrm{C}$ for $6 \mathrm{~h}$. Contents of $\mathrm{Na}^{+}$were determined by flame emission photometry (PFP7, Jenway, Stone, Staffordshire, UK).

Table 1. Description of treatments applied during $15 \mathrm{~d}$.

\begin{tabular}{llr}
\hline Treatments & \multicolumn{1}{c}{$\mathrm{NaCl}$} & $\mathrm{EC}$ \\
\hline & $\mathrm{mM}$ & $\mathrm{dS} \mathrm{m}$ \\
T1 (low salinity) & Hoagland's solution, 0 mM NaCl & 2.99 \\
T2 (intermediate) & Hoagland's solution, $50 \mathrm{mM} \mathrm{NaCl}$ & 8.75 \\
T3 (high salinity) & Hoagland's solution, $100 \mathrm{mM} \mathrm{NaCl}$ & 13.01 \\
\hline
\end{tabular}

EC: electrical conductivity.
Determination of relative membrane permeability, hydrogen peroxide, malondialdehyde, and ascorbic acid

Relative membrane permeability (EC \%) was calculated from measurements of electrolytic conductivity (Yang et al., 1996). The hydrogen peroxide $\left(\mathrm{H}_{2} \mathrm{O}_{2}\right)$ content was colorimetrically measured as described by Patterson et al. (1984). The content of $\mathrm{H}_{2} \mathrm{O}_{2}$ was calculated by comparison with a standard calibration curve, previously plotted by using different concentrations of $\mathrm{H}_{2} \mathrm{O}_{2}$. Oxidative damage to leaf lipids resulting from salt stress was estimated by the total content of 2-thiobarbituric acid reactive substances expressed as equivalents of malondialdehyde (MDA). The content of MDA was calculated using its absorption coefficient $(\varepsilon)$ and expressed as nmol MDA $\mathrm{g}^{-1}$ fresh mass (Cakmak and Horst, 1991). To extract and quantify the total ascorbic acid content (AsA and its oxidized form dihydroascorbic acid DHA) we used the method of Gossett et al. (1994), based on the reduction of $\mathrm{Fe}^{3+}$ to $\mathrm{Fe}^{2+}$ by AsA in an acid solution; absorption was measured at $525 \mathrm{~nm}$ and compared with a calibration curve previously prepared with AsA using the same procedure. Reduced AsA was quantified using the above procedure but using $0.1 \mathrm{~mL}$ distilled $\mathrm{H}_{2} \mathrm{O}$ instead of dithiothreitol (DTT). Concentration of DHA was calculated as the difference between total AsA and reduced AsA. Results were expressed in $\mathrm{nmol} \mathrm{g}^{-1} \mathrm{FW}$.

\section{Enzyme determinations}

Proteins were extracted from approximately $0.25 \mathrm{~g}$ fresh material and the slurry frozen at $-80{ }^{\circ} \mathrm{C}$ based on the method of Ferrario-Mery et al. (2002). The slurry was desalted with molecular exclusion columns packed with Sephadex G-25, diluting the sample with $100 \mathrm{mM}$ Tris-HCl buffer ( $\mathrm{pH}$ 8.0) and quantified in a molecular absorption spectrophotometer using the bicinchoninic acid method (Brown et al., 1989). Superoxide dismutase (SOD) activity was determined by measuring its capacity to inhibit the photochemical reduction of the chloride of nitrobluetretrazolium (NBT) (Giannopolitis and Ries, 1977). Absorbance was measured at $560 \mathrm{~nm}$; one unit of SOD activity (U) was defined as the quantity required to inhibit $50 \%$ of photoreduction rate of NBT. Results were expressed as $\mathrm{U} \mathrm{mg}^{-1}$ protein. Catalase (CAT) activity was determined by the method of Beers and Sizer (1952). We monitored decrease of $\mathrm{H}_{2} \mathrm{O}_{2}$ by the absorbance at $240 \mathrm{~nm}$ for $1 \mathrm{~min}$ from the moment $\mathrm{H}_{2} \mathrm{O}_{2}$ was added. The difference in absorbance $(\triangle \mathrm{A} 240)$ was divided by the coefficient of molecular extinction of $\mathrm{H}_{2} \mathrm{O}_{2}\left(36 \mathrm{mM}^{-1}\right.$ $\mathrm{cm}^{-1}$ ); CAT activity was expressed as $\mu \mathrm{mol}_{2} \mathrm{O}_{2} \mathrm{~min}^{-1}$ $\mathrm{mg}^{-1}$. Guaiacol peroxidase (GPX) activity was determined by the method of Urbanek et al. (1996). The oxidation of guaiacol (formation of tetraguaiacol) was monitored by the absorbance at $470 \mathrm{~nm}$ for $1 \mathrm{~min}$ from the moment $\mathrm{H}_{2} \mathrm{O}_{2}$ was added. The difference in absorbance $(\Delta \mathrm{A} 470)$ was divided by the coefficient of molecular extinction 
of tetraguaiacol $\left(26.6 \mathrm{mM}^{-1} \mathrm{~cm}^{-1}\right)$. The determination of ascorbate peroxidase (APX) activity was expressed as $\mu \mathrm{mol} \mathrm{H}_{2} \mathrm{O}_{2} \mathrm{~min}^{-1} \mathrm{mg}^{-1}$ protein, taking into account that 1 mol ascorbate is needed to reduce 1 mole $\mathrm{H}_{2} \mathrm{O}_{2}$ (McKersie and Leshem, 1994). The glutathione reductase (GR) activity was done using the method of Foyer and Halliwell (1976). The oxidation rate of NADPH was monitored by the absorbance at $340 \mathrm{~nm}$ for $1 \mathrm{~min}$ from the moment NADPH was added. The difference in absorbance ( $\triangle \mathrm{A} 340)$ was divided by the coefficient of molecular extinction of NADPH $\left(6.22 \mathrm{mM}^{-1} \mathrm{~cm}^{-1}\right)$; GR activity was expressed as $\mu \mathrm{mol}$ of NADPH $\mathrm{min}^{-1} \mathrm{mg}^{-1}$ protein.

\section{Experimental design and statistical analysis}

A factorial design in randomized complete block was used, with two factors: cultivars ('Lluteño' and 'Jubilee') and salinity $(0,50$, and $100 \mathrm{mM} \mathrm{NaCl})$ and five replicates for the measurements. All data were analyzed statistically by ANOVA using the Statgraphics Plus program 5.1 version (StatPoint Technologies, 2001). The Tukey's test was used for multiple comparisons with a $95 \%$ level of significance.

\section{RESULTS AND DISCUSSION}

\section{Effect of salinity on dry matter accumulation and $\mathrm{Na}^{+}$ content}

The increase of salts in the irrigation solution caused a significant decrease in growth of both corn cultivars. This effect was more pronounced in 'Jubilee', whose growth was reduced by $52.3 \%$ with $50 \mathrm{mM} \mathrm{NaCl}$ and $63.3 \%$ with $100 \mathrm{mM} \mathrm{NaCl}$ compared to the control, while the reduction in growth of 'Lluteño' was only $20.3 \%$ and $25.4 \%$ with 50 and $100 \mathrm{mM} \mathrm{NaCl}$, respectively (Figure $1 \mathrm{~A})$.

We observed wilting and leaf rolling only in 'Jubilee' with high salinity, but without necrosis of the leaf lamina. It has been reported that when cultivated at a concentration of soil salts of $40 \mathrm{mM}$, which generates an osmotic pressure of approximately $0.2 \mathrm{MPa}$, the majority of plant species reduce their production by $50 \%$ (Munns and Tester, 2008). Leaves and stems are the plant organs most sensitive to this osmotic effect, which has been observed in corn even in the absence of nutritional deficiencies and ionic toxicity (Hu et al., 2007). Root growth in 'Lluteño' appeared to be less affected by salinity than the aerial tissues (Carrasco-Ríos et al., 2013). In corn, for example, root cells are capable of recovering their turgor after an osmotic shock at a concentration of $150 \mathrm{mM} \mathrm{NaCl}$, while leaves do not recover completely (Frensh and Hsiao, 1994). However, mechanisms involved in this response are still unknown (Munns and Tester, 2008).

The growth inhibition produced by $\mathrm{NaCl}$ affect the entire plant in 'Jubilee', while it only affected leaf growth in 'Lluteño'; DM accumulation in stems and roots did not
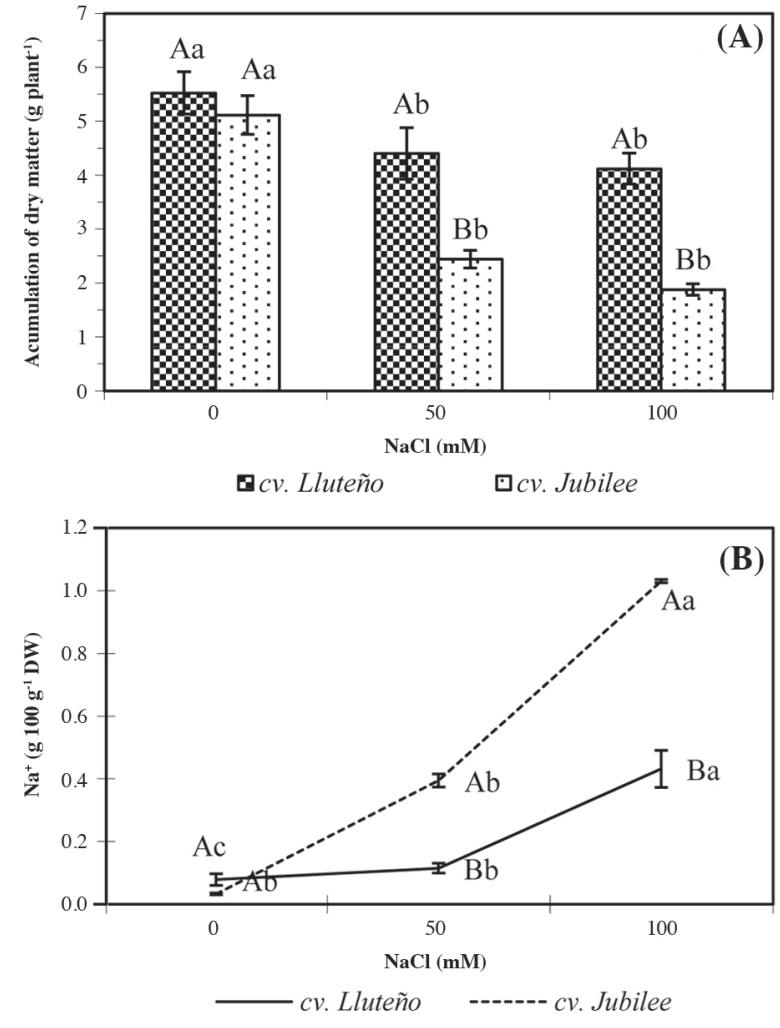

Values are the average of five replicates \pm standard error. Capital letters indicate comparisons between cultivars for the same treatment; lowercase letters indicate comparisons between treatments of the same cultivar. Distinct letters over the bars indicate differences according to Tukey test $(\mathrm{P} \leq 0.05)$

Figure 1. Effect of different $\mathrm{NaCl}$ concentrations on the accumulation of dry matter (A) and content of $\mathrm{Na}^{+}$in leaves (B) of 'Lluteño' and 'Jubilee' corn after $15 \mathrm{~d}$ of saline treatment.

vary significantly.

One of the criteria which indicate tolerance to salinity is the maintenance of the development of the root system. As the principal organ of absorption of water and ions, roots are very important in short and long term responses to salt stress; both anatomical and morphological characteristics of roots may affect capacity of adaptation of plants to salinity (Reinhardt and Rost, 1995; Maggio et al., 2001).

$\mathrm{NaCl}$ in the irrigation solution induced an increase in the concentration of $\mathrm{Na}^{+}$in leaves of both cultivars (Figure 1B) and roots (data not shown), especially in roots. It is known that $\mathrm{Na}$ concentration around the roots produces an increase in the electrochemical potential for $\mathrm{Na}$, which favors its passive transport from the exterior to the cytosol (Blumwald, 2000; Apse and Blumwald, 2002). 'Lluteño' accumulated less $\mathrm{Na}^{+}$in leaves than 'Jubilee'. Only $12.7 \%$ and $37.1 \%$ of total $\mathrm{Na}$ that 'Lluteño' plants contained at intermediate and high salinity was transported to leaves, while in 'Jubilee' these percentages were significantly greater, $44.6 \%$ and $62.1 \%$, respectively. 


\section{Effect of salinity on peroxide content}

Hydrogen peroxide is one of the most abundant and most stable ROS; it regulates several metabolic pathways acting as a molecular signal in processes of defense and development (Neill et al., 2002; Slesak et al., 2007). However, an increase in the $\mathrm{H}_{2} \mathrm{O}_{2}$ concentration in plant tissues may prejudice their growth due to the damage it produces in macromolecules, especially membrane lipids (Johnson et al., 2003). Figure 2A shows that salinity induced $\mathrm{H}_{2} \mathrm{O}_{2}$ production, which was double that control at intermediate salinity in both cultivars. However, at high salinity the peroxide content of 'Jubilee' was 8 times greater than control, while 'Lluteño' was only 3.6 times greater. These results demonstrate that salinity conditions
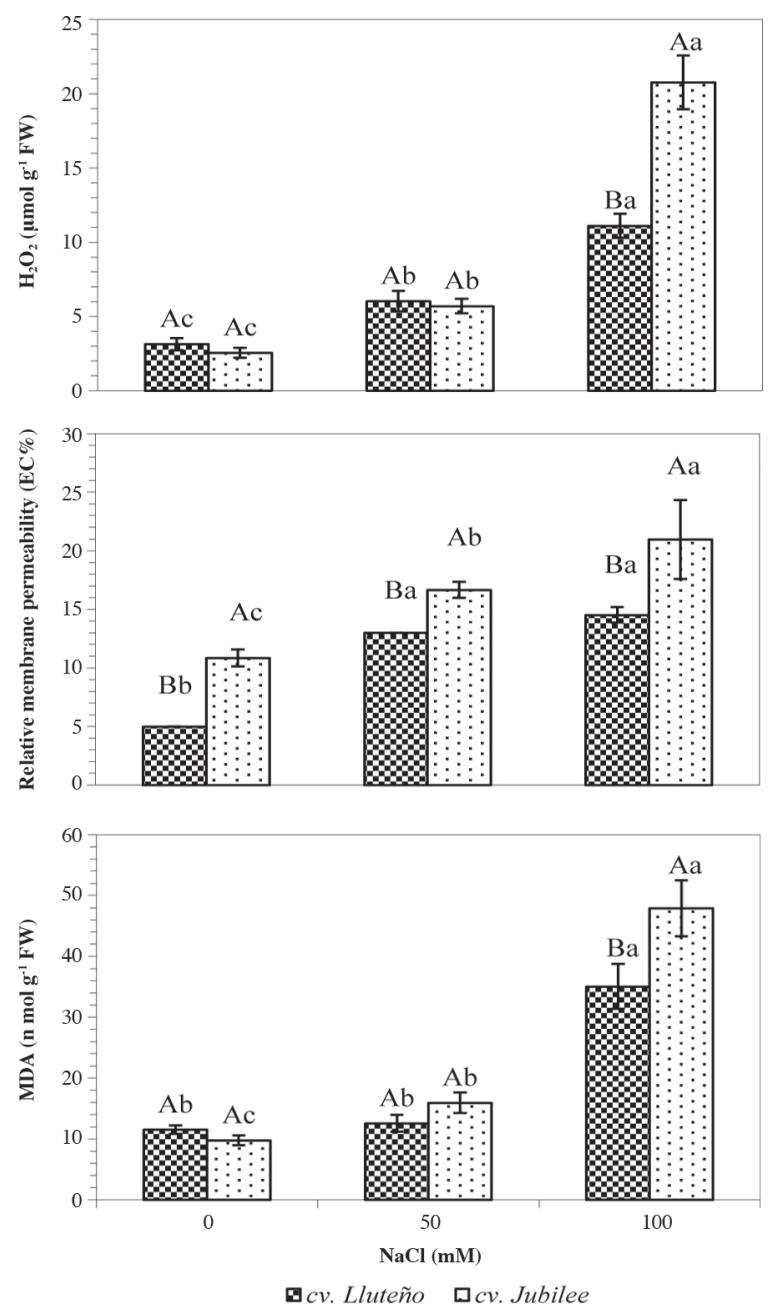

Values are the average of five replicates \pm standard error. Capital letters indicate comparisons between cultivars for the same treatment; lowercase letters indicate comparisons between treatments of the same cultivar. Distinct letters over the bars indicate differences according to Tukey test $(\mathrm{P} \leq 0.05)$.

Figure 2. Effect of different $\mathrm{NaCl}$ concentrations on the membrane permeability, content of peroxide $\left(\mathrm{H}_{2} \mathrm{O}_{2}\right)$, and content of malondialdehyde (MDA) in leaves of 'Lluteño' and 'Jubilee' corn after $15 \mathrm{~d}$ of saline treatment. employed in this study induced oxidative damage in the studied cultivars, and that 'Jubilee' was more affected by high salinity.

\section{Effect of salinity on membrane permeability}

The leak of solutes was evaluated to determine damage to the cell membrane provoked by $\mathrm{NaCl}$. Figure $2 \mathrm{~B}$ shows that the loss of solutes increased with increasing salinity; electrolyte loss was greater in 'Jubilee'. Several studies have demonstrated that plasma membrane is the part of the cell that first confronts salt, and that it must be less susceptible and maintain its integrity in conditions of high salt to fulfill its selective function, regulation of the passage of water, ions, metabolites and electrochemical potential (Spector and Yorek, 1985). For this reason the stability of plasma membrane has been widely used to differentiate cultivars which are tolerant or sensitive to salinity. In many cases high membrane stability is directly correlated with tolerance to abiotic stress (Mansour, 1997; Masood et al., 2006).

\section{Effect of salinity on MDA content}

Malondialdehyde is produced when the polyunsaturated fatty acids of the plasma membrane are peroxidized, and represents the expression of the oxidative damage. The increase in salinity induced an increase in MDA content in both corn cultivars (Figure 2C), especially at high salinity; 'Jubilee' had a greater degree of lipid peroxidation in the cell membrane than 'Lluteño' at high salinity. A number of studies have shown that salt stress produces alterations in structure and composition of plasma membrane lipids, such as the increase in degree of saturation of free fatty acids and increase in free sterols, which leads to a decrease in the fluidity of cell membrane (Mansour et al., 2005). However, it is not clear whether the saturation of membrane lipids has an adaptive value, if there is a correlation between a specific class of lipids and salt tolerance, or if it is just a negative effect of salinity (Mansour and Salama, 2004).

Salinity appears to have produced lower levels of lipid peroxidation and less loss of electrolytes in 'Lluteño' than in 'Jubilee', which is related to the greater salt tolerance of 'Lluteño'. Similar results were reported by Azevedo Neto et al. (2006), who found that the peroxidation of lipids was increased by salinity in sensitive corn genotypes.

\section{Effect of salinity on the activity of SOD, CAT, and GPX}

Superoxide dismutase activity decreased with increasing salinity in both corn cultivars; however, 'Lluteño' had a specific activity 1.5 to 1.7 times greater than 'Jubilee' in all treatments (Figure 3A). Superoxide dismutase is the main enzyme which traps ROS, and is found in almost all cell compartments. High SOD levels have been found in salt-resistant plants (Gosset et al., 1994; Hernandez et al., 1995a; 1995b), and constitutive high levels of this enzyme 

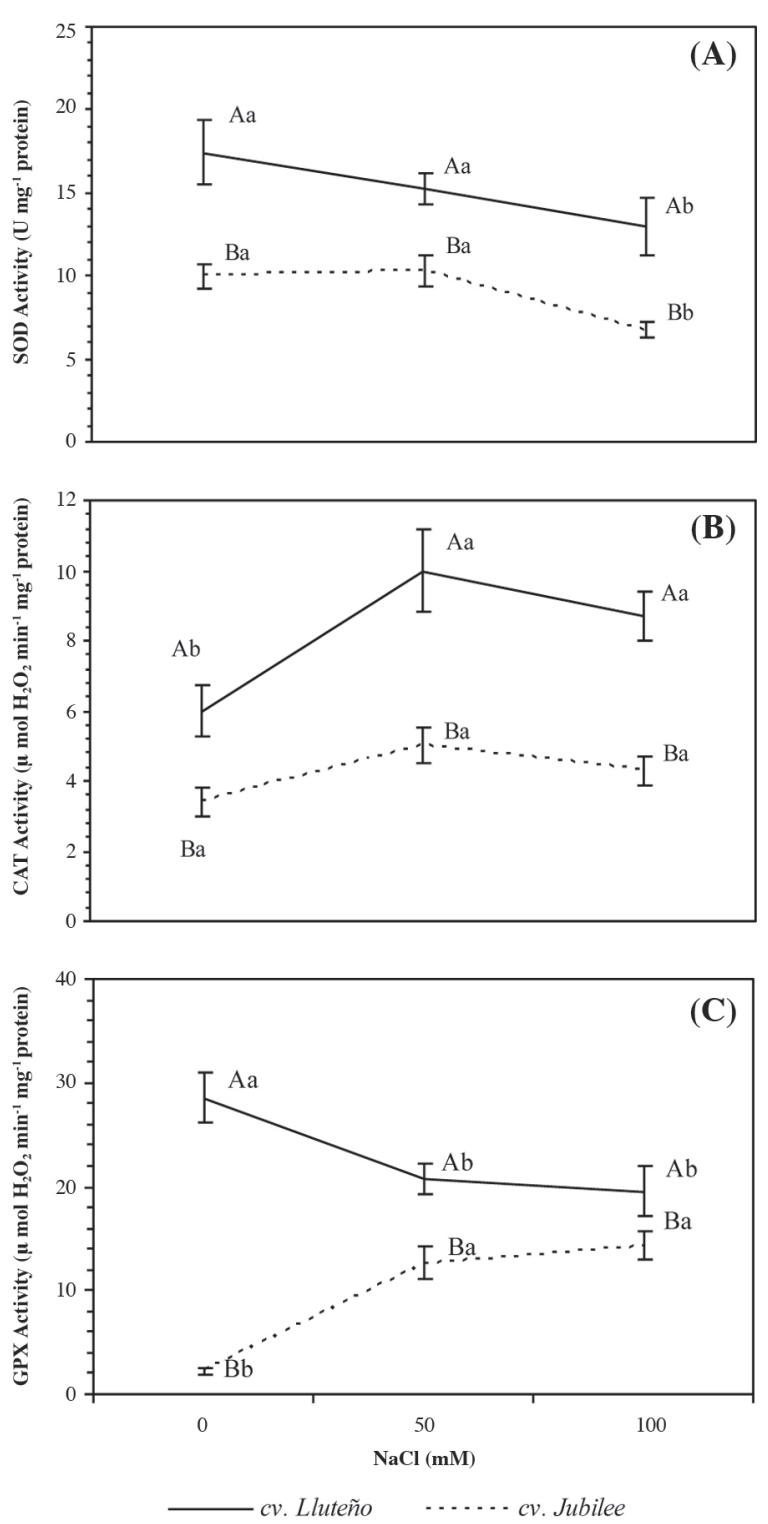

Values are the average of five replicates \pm standard error. Capital letters indicate comparisons between cultivars for the same treatment; lowercase letters indicate comparisons between treatments of the same cultivar.

Figure 3. Effect of different $\mathrm{NaCl}$ concentrations on the activity of superoxide dismutase (SOD), catalase (CAT), and guaiacol peroxidase (GPX) in leaves of 'Lluteño' and 'Jubilee' corn after 15 d of saline treatment.

are correlated with salt tolerance (Acar et al., 2001).

It is well known that SOD converts superoxide $\left(\mathrm{O}_{2}{ }^{-}\right)$ radical to $\mathrm{H}_{2} \mathrm{O}_{2}$; thus an increase in $\mathrm{H}_{2} \mathrm{O}_{2}$ production will require an increase in the capacity of rapid removal of the $\mathrm{H}_{2} \mathrm{O}_{2}$ generated by SOD. Catalase participates in this action, its activity increased in 'Lluteño' in saline treatments and was $50 \%$ greater than the activity in 'Jubilee' in all treatments (Figure 3B). By contrast, in 'Jubilee' there was no significant variation in CAT activity under saline conditions.

Corn plants have three known isoforms of catalase: cat-1, cat-2 (peroxisome and cytosol), and cat-3 (mitochondria) located on different chromosomes and regulated independently (Polidoros and Scandalios, 1999). Catalase is indispensable in detoxification when ROS levels increase due to stress (Foyer et al., 1994; Willekens et al., 1997).

The increase of CAT in 'Lluteño' agrees with the results of Lopez-Huertas et al. (2000), who showed that $\mathrm{H}_{2} \mathrm{O}_{2}$ induces peroxisome gene biogenesis in plant and animal cells. These authors suggested that a number of stress situations which cause the production of $\mathrm{H}_{2} \mathrm{O}_{2}$ can be mitigated by proliferation of peroxisomes generated to restore the cell redox equilibrium.

The guaiacol peroxidases (GPX), which are also involved in the catabolism of $\mathrm{H}_{2} \mathrm{O}_{2}$ in the cytosol, vacuole and cell wall (Asada, 1992), decreased their activity under saline conditions in 'Lluteño'. By contrast, GPX levels increased significantly with saline conditions in 'Jubilee'; however, the specific activity of these enzymes was greater in 'Lluteño' in all treatments.

\section{Effect of salinity on the activity of APX and GR}

Ascorbate peroxidase (APX) is involved in the ascorbateglutathione cycle, which has an important role in the protection of plants from the $\mathrm{H}_{2} \mathrm{O}_{2}$ that results from normal photosynthetic activity and in situations of environmental stress (Noctor and Foyer, 1998). Activity of APX did not vary significantly in 'Jubilee' due to salinity, while the activity decreased by about 35\% in 'Lluteño' with high salinity (Figure 4). Ascorbate peroxidase uses ascorbate (AsA) as an electron donor; AsA content was affected by high salinity conditions in 'Lluteño', however, there was an increase in this compound in 'Jubilee' (Table 2). Since AsA may eliminate $\mathrm{O}^{*}, \mathrm{OH}^{*}$ and oxygen singlets $\left({ }^{1} \mathrm{O}_{2}\right)$ directly as well as reducing $\mathrm{H}_{2} \mathrm{O}_{2}$ to $\mathrm{H}_{2} \mathrm{O}$ via the ascorbateglutathione cycle (Noctor and Foyer, 1998). Ascorbate may also remove oxygen free radicals directly with or without enzymatic catalysis, recycled to its reduced form tocopherol (Zhang, 2013). Furthermore, chloroplast AsA acts as a cofactor for violaxanthin deepoxidase, an enzyme involved in xanthophyll cicle-mediated photoprotection (Smirnoff and Wheeler, 2000). While the increase of AsA in plants of 'Jubilee' could suggest an important role of this antioxidant in salt stress, you may also be an indicator of photoinhibition (Smirnoff, 2011). In Arabidopsis leaves, the AsA accumulation is increased by high light along with the expression and activity of GDP-L-galactose phosphorylase, the enzyme responsible for ascorbate synthesis (Smirnoff, 2011).

The content of DHA, a compound which recycles AsA via dehydroascorbate reductase (DHAR), decreased significantly in 'Lluteño' with $100 \mathrm{mM} \mathrm{NaCl}$, while in 'Jubilee' DHA decreased by 2.8 and 4.6 times the control value under saline conditions (Table 2).

The regeneration of AsA from DHA is a process of considerable importance in the anti-oxidation response. 

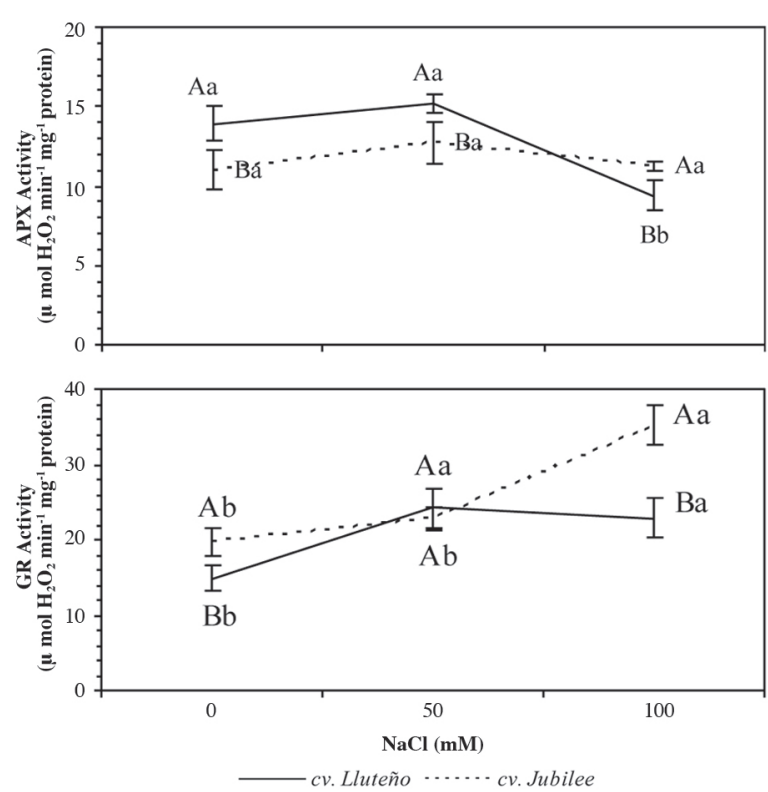

Values are the average of five replicates \pm standard error. Capital letters indicate comparisons between cultivars for the same treatment; lowercase letters indicate comparisons between treatments of the same cultivar.

Figure 4. Effect of different $\mathrm{NaCl}$ concentrations on the activity of ascorbate peroxidase (APX) and glutathione reductase (GR) in leaves of 'Lluteño' and 'Jubilee' corn after $15 \mathrm{~d}$ of saline treatment.

Table 2. Ascorbate (AsA) and dehydroascorbate (DHA) content in leaves of 'Lluteño' and 'Jubilee' corn under different $\mathrm{NaC}$ concentrations.

\begin{tabular}{rcrc}
\hline & \multicolumn{3}{c}{ 'Lluteño' } \\
\cline { 2 - 4 } $\begin{array}{c}\text { Treatment } \\
\mathrm{NaCl}\end{array}$ & Ascorbate & Dehydroascorbate & $\begin{array}{c}\text { Ratio } \\
\text { AsA/DHA }\end{array}$ \\
\hline $\mathrm{mM}$ & $\mathrm{nmol} \mathrm{g}^{-1} \mathrm{FW}$ \\
0 & $47.39 \pm 4.30 \mathrm{Aa}$ & $46.28 \pm 5.80 \mathrm{Aa}$ & 1.02 \\
50 & $43.89 \pm 4.70 \mathrm{Aa}$ & $49.12 \pm 8.11 \mathrm{Aa}$ & 0.89 \\
100 & $36.73 \pm 2.58 \mathrm{Bb}$ & $19.75 \pm 5.21 \mathrm{Ab}$ & 1.86 \\
& & 'Jubilee' & \\
0 & $41.05 \pm 3.27 \mathrm{Ab}$ & $50.63 \pm 9.79 \mathrm{Aa}$ & 0.81 \\
50 & $51.42 \pm 6.24 \mathrm{Aa}$ & $18.16 \pm 3.68 \mathrm{Bb}$ & 2.83 \\
100 & $56.37 \pm 3.21 \mathrm{Aa}$ & $11.09 \pm 2.19 \mathrm{Ab}$ & 5.08 \\
\hline
\end{tabular}

Values are the average of five replicates \pm standard error. Capital letters indicate comparisons between cultivars for the same treatment; lowercase letters indicate comparisons between treatments of the same cultivar

Dehydroascorbate reductase is involved in this process, using the reducing power of reduced glutathione; the resulting oxidized glutathione is recycled by the action of glutathione reductase (GR). Therefore the increase in GR activity observed in both corn cultivars due to salinity is directly correlated with the lower DHA content shown by both varieties, although the activity of this enzyme was significantly greater in 'Jubilee'. Gosset et al. (1994; 1996) showed that salt-tolerant cotton varieties had a high GR activity, favoring a greater AsA/DHA ratio as we found in 'Jubilee' (Table 2). Thus 'Jubilee' appears to use principally the ascorbate-glutathione cycle to deactivate the ROS generated by energy-producing pathways under conditions of saline stress. This alternative mechanism for removing $\mathrm{H}_{2} \mathrm{O}_{2}$ could compensate for the low CAT activity that presents the 'Jubilee' (Figure 3).
A number of studies have indicated that salttolerant plants can induce activity of antioxidant enzymes (Masood et al., 2006; Ashraf and Ali, 2008), and there are also several reports of wild crops which have prospered in conditions of natural stress which have enzymatic antioxidant mechanisms which are constitutively superior than cultivated varieties of these crops (Shalata and Tal, 1998). The characteristics we report for 'Lluteño', including enzymatic anti-oxidant mechanisms, the ability to restrict the passage of salts to the aerial tissues and/or utilize them for osmotic adjustment, maintain a greater concentration of $\mathrm{K}^{+}$and $\mathrm{Ca}^{2+}$ in leaves in relation to the increase of $\mathrm{Na}^{+}$may all contribute to salt tolerance that this corn variety possesses (Carrasco-Ríos et al., 2013).

\section{CONCLUSION}

The saline conditions applied in this study induced the formation of reactive oxygen species (ROS) and lipid peroxidation in both corn cultivars. However, 'Lluteño' has an enzymatic anti-oxidation system which is constitutively more active than that of 'Jubilee'. Consequently this characteristic may be considered to be a defense mechanism which contributes to the tolerance of the oxidative effect of salinity, and thus the oxidative damage in 'Lluteño' was less than in 'Jubilee'.

\section{ACKNOWLEDGEMENTS}

This report is part of the requirements for the Doctoral Degree in Ciencias Silvoagropecuarias of the Facultad de Ciencias Agronómicas, Universidad de Chile given to Libertad Carrasco-Ríos. The research was funded by the Universidad de Tarapacá and CONICYT through the Centro de Investigaciones del Hombre en el Desierto (CIHDE).

\section{LITERATURE CITED}

Acar, O., I. Turkan, and F. Ozdemir. 2001. Superoxide dismutase and peroxidase activities in drought sensitive and resistant barley (Hordeum vulgare L.) varieties. Acta Physiologiae Plantarum 3:351-356.

Apse, M.P., and E. Blumwald. 2002. Engineering salt tolerance in plants. Current Opinion in Biotechnology 13:146-150.

Arnon, D.I., and D.R. Hoagland. 1940. Crop production in artificial culture solutions and in soil with special reference to factors influencing yields and absorption of inorganic nutrient. Soil Science 50:463-483.

Asada, K. 1992. Ascorbate peroxidase -a hydrogen peroxidescavenging enzyme in plants. Physiologia Plantarum 85:235-241.

Ashraf, M., and Q. Ali. 2008. Relative membrane permeability and activities of some antioxidant enzymes as the key determinants of salt tolerant in canola (Brassica napus L.) Environmental and Experimental Botany 63:266-273.

Azevedo Neto, A.D., J.T. Prisco, J. Eneas-Filho, C.E. Braga de Abreu, and E. Gomes-Filho. 2006. Effects of salt stress on antioxidative enzymes and lipid peroxidation in leaves and root of salt-tolerant and salt-sensitive maize genotypes. Environmental and Experimental Botany 56:87-94. 
Beers, R.F., and I.W. Sizer. 1952. A spectrophotometric method for measuring the breakdown of hydrogen peroxide by catalase. Journal of Biological Chemistry 195:133-140.

Blumvald, E. 2000. Sodium transport and salt tolerance in plants. Current Opinion in Cell Biology 12:431-434.

Brown, R.E., K.L. Jarvis, and K.J. Hyland. 1989. Protein measurement using bicinchoninic acid: Elimination of interfering substances. Analytical Biochemistry 180:136-139.

Cakmak, I., and J. Horst. 1991. Effect of aluminium on lipid peroxidation, superoxide dismutase, catalase, and peroxidase activities in root tips of soybean (Glycine max). Physiologia Plantarum 83:463-468.

Carrasco-Ríos, L., C. Rojas, and M. Pinto. 2013. Contrasting physiological responses to high salinity between two varieties of corn 'Lluteño' (salt tolerant) and 'Jubilee' (salt sensitive). Chilean Journal of Agricultural Research 73:205-212.

Ferrario-Mery, S., M. Hodges, B. Hirel, and C.H. Foyer. 2002. Photorespiration-dependent increases in phosphoenolpyruvate carboxylase, isocitrate dehydrogenase and glutamate dehydrogenase in transformed tobacco plants deficient in ferredoxin-dependent glutamine-alpha-ketoglutarate aminotransferase. Planta 214:877-886.

Filella, I., L. Serrano, J. Serra, and J. Peñuelas. 1995. Evaluating wheat nitrogen status with canopy reflectance indices and discriminant analysis. Crop Science 35:1400-1405.

Foyer, C.H., and B. Halliwell. 1976. The presence of glutathione and glutathione reductase in chloroplasts: a proposed role in ascorbic acid metabolism. Planta 133:21-25.

Foyer, C.H., M. Lelandais, and K.J. Kunert. 1994. Photooxidative stress in plants. Physiologia Plantarum 92:696-717.

Frensh, J., and T.C. Hsiao. 1994. Transient responses of cell turgor and growth of maize roots as affected by changes in water potential. Plant Physiology 104:247-254.

Giannopolitis, C.N., and S.K. Ries. 1977. Superoxide dismutases. I. Occurrence in higher plants. Plant Physiology 59:309-314.

Gosset, D.G., S.W. Banks, E.P. Millhollon, and M.C. Lucas. 1996. Antioxidant response to $\mathrm{NaCl}$ stress in a control and an $\mathrm{NaCl}-$ tolerant cotton cell line grown in the presence of paraquat, buthionine, sulfoximine, and exogenous glutathione. Plant Physiology 112:803-809.

Gosset, D.G., E.P. Millhollon, M.C. Lucas, S.W. Banks, and M.M. Marney. 1994. The effects of $\mathrm{NaCl}$ on antioxidant enzyme activities in callus tissue of salt-tolerant and salt-sensitive cultivars (Gossipium hirsutum L.) Plant Cell Reports 13:498-503.

Hernandez, J.A., F.J. Corpas, M. Gomez, L.A. del Rio, and F. Sevilla. 1995a. Salt induced oxidative stress mediated by activated oxygen species in pea leaf mitochondria. Physiology Plant 89:103-110.

Hernandez, J.A., A. Jimenez, P. Mullineaux, and F. Sevilla. 2000. Tolerance of pea (Pisum sativum L.) to long term salt stress is associated with induction of antioxidant defenses. Plant Cell Environmental 23:853-862.

Hernandez, J.A., E. Olmos, F.J. Corpas, M. Gomez, F. Sevilla, and L.A. del Rio. 1995b. Salt induced oxidative stress in chloroplasts of pea plant. Plant Science 105:151-167.

Hu, Y., Z. Burucs, S. von Tucher, and U. Schmidhalter. 2007. Shortterm effects of drought and salinity on mineral nutrient distribution along growing leaves of maize seedlings. Environmental Experimental Botany 60:268-275.

Imlay, J.A. 2003. Pathways of oxidative damage. Annual Review of Microbiology 57:395-418.

Johnson, S.M., S.J. Doherty, and R.R.D. Croy. 2003. Biphasic superoxide generation in potato tubers: a self amplifying response to stress. Plant Physiology 13:1440-1449.

Lawlor, D.W. 1995. The effects of water deficit on photosynthesis. p. 129-160. In N. Smirnoff (ed.) Environment and plant metabolism. Bios Scientific Publishers, Oxford, UK.

Lopez-Huertas, E., W.L. Charlton, B. Johnson, I.A. Graham, and A. Baker. 2000. Stress induces peroxisome biogenesis genes. The European Molecular Biology Organization Journal 19:6770-6777.

Maggio, A., P.M. Hasegawa, R.A. Bressan, M.F. Consiglio, and R.J. Joly. 2001. Unravelling the functional relationship between root anatomy and stress tolerance. Australian Journal of Plant Physiology 28:999-1004.
Mansour, M.M.F. 1997. Cell permeability under salt stress. p. 87110. In Jaiwal, P.K., R.P. Singh, and A. Gulati (eds.) Strategies for improving salt tolerance in higher plants. Oxford and IBH, New Delhi, India.

Mansour, M.M.F., and K.H.A. Salama. 2004. Cellular basis of salinity tolerance in plants. Environmental and Experimental Botany 52:113-122.

Mansour, M.M.F., K.H.A. Salama, F.Z.M. Ali, and A.F. Abou Hadid. 2005. Cell and plant responses to $\mathrm{NaCl}$ in Zea mays L. cultivars differing in salt tolerance. General and Applied Plant Physiology 31:29-41

Masood, A., N.A. Shah, M. Zeeshan, and G. Abraham. 2006. Differential response of antioxidant enzymes to salinity stress in two varieties of Azolla (Azolla pinnata and Azolla filiculoides). Environmental and Experimental Botany 58:216-222.

McKersie, D., and Y. Leshem. 1994. Stress and stress coping in cultivated plants. Kluwer Academic Publishers, London, UK.

Munns, R. 2002. Comparative physiology of salt and water stress. Plant, Cell and Environment 25:239-250.

Munns, R., and M. Tester. 2008. Mechanisms of salinity tolerant. Annual Review of Plant Biology 59:651-681.

Neill, S.J., R. Desikan, A. Clarke, R.D. Hurst, and J.T. Hancock. 2002. Hydrogen peroxide and nitric oxide as signaling molecules in plants. Journal of Experimental Botany 53:1237-1247.

Noctor, G., and C. Foyer. 1998. Ascorbate and glutathione: keeping active oxygen under control. Annual Review of Plant Physiology and Plant Molecular Biology 49:249-279.

Patterson, D., A. MacRae, and B. Ferguson. 1984. Estimation of hydrogen peroxide in plant extracts using titanium (IV). Annals of Biochemistry 139:487-492.

Polidoros, A.N., and J.G. Scandalios. 1999. Role of hydrogen peroxide and different classes of antioxidants in the regulation of catalase and glutathione S-transferase gene expression in maize (Zea mays L.) Physiologia Plantarum 106:112-120.

Reinhardt, D.H., and T.L. Rost. 1995. Salinity accelerates endodermal development and induces an exodermis in cotton seedling root. Environmental and Experimental Botany 35:563-574.

Shalata, A., and M. Tal. 1998. The effect of salt stress on lipid peroxidation and antioxidants in the leaf of the cultivated tomato and its wild salt-tolerant relative Lycopersicon pennelli. Physiologia Plantarum 104:169-174.

Slesak, I., M. Libik, B. Karpinska, S. Karpinski, and Z. Miszalski. 2007. The role of hydrogen peroxide in regulation of plant metabolism and cellular signaling in response to environmental stresses. Acta Biochimica Polonica 54:39-50.

Smirnoff, N. 2011. Vitamin C: the metabolism and functions of ascorbic acid in plants. Advances in Botanical Research 59:107-177.

Smirnoff, N., and G.L. Wheeler. 2000. Ascorbic acid in plants: biosynthesis and function. Critical Reviews in Plant Sciences 19:267-290.

Spector, A., and A. Yorek. 1985. Membrane lipid composition and cellular functions. Journal of Lipid Research 26:1015-1035.

StatPoint Technologies. 2001. Statgraphics Plus 5.1. StatPoint Technologies, Warrenton, Virginia, USA.

Urbanek, H., E. Gajewaska, R. Karwawska, and M. Wielanek. 1996. Generation of superoxide anion and induction of superoxide dismutase and peroxidase in leaves infected with pathogenic fungi. Acta Biochimica Polonica 43:679-685.

Willekens, H., S. Chamnongpol, M. Davey, M. Schraudner, C. Langebartels, M. van Montagui, et al. 1997. Catalase is a sink for $\mathrm{H}_{2} \mathrm{O}_{2}$ and is indispensable for stress defence in C-3 plants. The European Molecular Biology Organization Journal 16:4806-4816.

Yang, G., D. Rhodes, and R.J. Joly. 1996. Effect of high temperature on membrane stability and chlorophyll fluorescence in glycinebetaine-containing maize lines. Australian Journal Plant Physiology 23:431-443.

Zhang, Y. 2013. Ascorbic acid in plants. Biosynthesis, regulation and enhancement. Springer Briefs in Plant Science nr 14. 117 p. Springer, New York, USA. 